\title{
Top countries tackling Covid-19 - Success stories
}

\author{
Shipra Agarwal ${ }^{1}$
}

\section{$\underline{\text { Abstract }}$}

The world is under pressure from the novel COVID-19 pandemic, bringing the total number of confirmed cases to more than 81 lakh globally. Coronavirus cases were found earlier in China and later on spread all over the world and became a global pandemic in March 2020. This paper presents countries that have best performed with almost no new cases coming up. Countries such as Taiwan, Vietnam, New Zealand, Australia, Japan and Germany have different responses to COVID-19 in between January and June 2020. The paper highlights the actions taken by the governments or at the community level.

\section{Introduction}

These countries have been leading in the ranking of the best Covid-19 response systems across the world. The countries successfully contained the spread of coronavirus and reported a decline in new coronavirus cases. Now, a few countries yet not reporting any case and have so far recovered from Covid-19 (1). What is the success story of the best-performing nations in the world?

Response strategy is something very important. Not all countries have the same emphasis on the overall goal of the strategic preparedness and response plan to stop further transmission of 2019-nCoV. One country performed better than the other.

An elimination strategy requires highly functioning public health infrastructure. Increasingly, traditional approaches are supported by newer tools such as the use of digital technology to speed up contact tracing (1). Additional surveillance approaches can be used to provide increased assurance of elimination (eg, sentinel surveillance, sewage testing). However, even in the presence of a highly sophisticated surveillance system, the transmission will continue to occur if isolation and quarantine adherence are suboptimal.

\footnotetext{
${ }^{1}$ Shipra Agarwal is a Research associate of a Think Tank, Sanrachna. Affiliated by SGT University, Gurugram F-29, Ansari Market, Dariyaganj, Delhi - 110057 Ph. No. 9675753995
} 


\section{Chronology of Covid-19 outbreak}

On 31 December 2019, the World Health Organization (WHO) was notified about a cluster of pneumonia patients in Wuhan City, Hubei Province of China. On 7 January 2020, Chinese authorities confirmed that they had identified a novel coronavirus as the cause of pneumonia. Human to human transmission was the suggested fact of the spread of Covid-19. The first fatal case was reported on 11th of January and consequently, in a week, the cases started spreading in other provinces of China, other countries (Thailand, Japan and South Korea) (2). On the 7th of March, it was found that it has affected 100 countries all over the world. Thus, the World Health Organization declared Covid-19 a global pandemic on 11th March 2020.

Wuhan in China which is the epicentre of the Covid-19 virus had moved swiftly to prevent the spread. Followed by the announcement of an emergency, it had constructed new hospitals in late January. China took strict decisions to stop the spread of the disease using digital surveillance for Covid-19 tracking. China used a combination of high tech- scanning of its population through contact tracing, using AI-based contactless temperature detection software and facial recognition technology and automated vehicle, and 5G technology in Wuhan was used for telemedical care for highly infected areas. During the early days of March, there were affected people arriving from overseas to Beijing, thus China banned entry from overseas flights to Beijing and cancelled the flights and made some hospitals as specialized hospitals for affected people. China's strong governance was to strictly restrict community transmission by maintaining the entry and exit in all areas.

\section{Countries with the best response to Covid-19}

\section{$\underline{\text { Taiwan }}$}

Taiwan was expected to have the 2nd highest number of COVID-19 cases due to a cross border connection with china. The country has 23 million people, high densely populated urban areas and has many citizens reside and work in China. However, the country has earned the world's admiration for its fast and highly effective response to the coronavirus pandemic. The country had managed to keep itself out of the virus as it has 443 cases with only 7 deaths. The key to the success of the 0-2 new cases in Taiwan is the quick response and effective surveillance by the government (1). Taiwan announced medical advisory very early as on 31st December to bound visitors from Wuhan with 14- days self -vigilance, wearing masks, and temperature check and medical test. However, its first confirmed case was reported on 21st January. The government implemented travel restrictions and banned flights from Wuhan on 23rd January. In addition to preventing panic buying, the government bought masks and distributed through the national insurance card system. Moreover, made a provision of free treatment for those infected are not insured, allowance for 
medical staff. In March, the entries from Europe and the Middle East were restricted and further announced a total travel ban till 7th April. Social gatherings of not more than 100 people in a place were allowed. It did not implement lockdown and it controlled the spread with the early response to the risk of infection; mitigation is the key to controlling it (3).

By the end of January, for case identification and containment, Taiwan used new technologies like scanning through QR codes and online reporting of travel history and strengthens case identification through rollout testing, containment, and resource allocation to protect the public health. People with high risk were quarantined at home and tracked through their mobile phones. And those with low risk with no travel to high alert areas provided with the health declaration pass via SMS that had given access to patients to all hospitals, clinics, and pharmacies to know the status of the patients. Further, the government increased the production of medical supplies by resource allocation and ensured the availability of PPE by banning exports (4).

\section{New Zealand}

New Zealand has a relatively low rate of infections than many other countries. It has 1504 confirmed and probable cases and has recovered almost 98 per cent of cases with only 22 deaths. New Zealand has just 5 million people; it is among the least densely populated country (5). New Zealand has a maximum number of its cases imported and those who have close contacts. Earlier like other western countries, New Zealand was following its existing plan on a mitigation approach by implementing social distancing and managing health services. However, towards the end of March, just after its first case New Zealand committed the elimination strategy by announcing an intense lockdown carried out to contain the spread of the virus. Additionally, closure of borders, early risk assessment by improved identification their contact persons through contact tracing and the robust case identification and surveillance plan undertook large scale testing to test all suspected cases assured that there were no missing cases (6). New Zealand is performing so well more than 150000 people have been tested with an outstanding recovery rate. The testing was more focused on specific communities who are at higher risk of acquiring the virus such as those in aged residential care and health-care workers (7). A prevention strategy was used for all the overseas travellers if symptomatic on arrival were quarantined for 14 days and those not symptomatic on arrival were isolated for 14 days. This will be used for future also. In New Zealand, the strong community support for government strategies, effective communication and effective use of PPE saved its public health that put lessons for others of its best use of elimination strategy to control the COVID-19 pandemic(8).

\section{Germany}


Germany the only country in Europe, with a large number of cases to 188044 however controlled its deaths to 8885 and now zero new cases are reported (1). Comparing the fatalities to its population of 83 million, Germany looks stronger being the best-performed country in Europe. The first confirmed case of COVID19 occurred in Germany on January 27. In Mid-March of 2020, numerous measures were introduced to slow the spread that was swift and generous. Germany is an exception due to its medical preparedness by maintaining its operational capacities such as ICU capacity and testing kits. The government had promised financial bonuses to hospitals if they increase and maintain intensive care beds. The federal government has never implemented a complete lockdown nationwide, however, its ban on gatherings of more than two people and has closed non-essential services and imposed strict entry regulations (9). Apart from that, Germany has managed the technological edge, and leadership, the early diagnostics was started on a large scale and the costs of the COVID-19 tests are covered by the Statutory Health Insurance (SHI) for a payment EUR 59 per test. In Germany, people had full access to medical care $\left({ }^{10}\right)$.

\section{$\underline{\text { Australia }}$}

Australia being an only oceanic country with the largest caseload of Covid-19 is on a similar success path to New Zealand. However, Australia has not been as hard-hit by the pandemic, reporting around 7335 cases of the virus and 102 deaths till now (11).In early March, Australia's primary care response to COVID-19 was the protection of vulnerable people, preserving the capacity of the healthcare system to manage the caseload, protection to healthcare workers in primary care through availability of Personal Protective Equipment (PPE) and supporting most effective management in primary care of people with symptoms due to Covid-19(12). Moreover, a part of these mitigation measures, the Australian government has responded to the pandemic by restricting travel and closing borders for non-citizens to slow the rate of infections. Further, Social distancing measures have been enforced to reduce spread within communities and isolation has been encouraged for the population (13).

\section{$\underline{\text { Vietnam }}$}

Vietnam shares a bustling border with China, despite limited resources and massive volume of trade with China, only 334 Covid-19 cases of which 323 recovered with no new cases and zero death confirmed with 97.3 million populations(1). It has managed to contain the pandemic exceptionally well with its prompt and aggressive response. The main source of infection was associated with travel from China and European nations, and then the cases have increased due to the local transmission. Vietnam is a middle-income country did not apply mitigation measures and became a notable exception, implementing stringent control including quarantine, contact tracing, border controls, school closures, and traffic restrictions while case 
numbers were still low. Since its first case of Covid-19 was announced on 23rd January, it suspended flights and imposed travel restrictions in late January and a local quarantine in mid-February for 14 days in quarantine camps run by the military during mid-February. The monitoring strategies implemented and effective communication with citizens help enforce government restrictions. The health ministry strategic move was a combination of extensive efforts includes isolating infected people and tracing and quarantining their contacts (14). Violators will be fined in between \$426 and \$853 (VND 10-20 million). Later on, Vietnam imposed a lockdown on 1st April and in less than a month the country has lifted it on 23rd April with some strict restrictions of social distancing, schools were closed, cancelled all large events and public gatherings were allowed for not more than 20 people. However, Vietnam did not implement lockdown of entire cities where infected cases had occurred (15).

\section{$\underline{\text { Japan }}$}

Japan is an Asian country had reported its first case in mid of January and now it has 17502 cases of Covid19 and 925 deaths however no new cases. In the early February, the case in a "Diamond Princess" Cruise ship was reported on its arrival, Hence, the passengers in the ship were ordered to quarantine. At the end of February, after a gradual spread of cases, Japan evacuated more than 800 Japanese nationals from Wuhan through five chartered flight. It restricted entry to the border of visitors from Hubei to the country and later imposed a travel ban and quarantine restrictions on many countries. Japan was then shifted its focus from containment to prevention and treatment. It used the cluster approach and started extensive contact tracing to identify the cluster to spread the disease. The country did not impose a strict lockdown lacking the power of legal enforcement. Japan's government approach was to work on strengthening the medical system as they had enough time and resources to respond to the situation. The country's early actions such as avoiding large public gatherings, postponed the Olympics, border control, promoting telework very strongly (5).

\section{Conclusion}

The importance of the implementation of different government's measures in the countries is vital for the better health safety of their citizens. Taiwan, New Zealand, Germany, Japan, Vietnam and Australia paid great attention to ensure public health protection. The contrast between the different countries is based on two different strategies; mitigation or suppression. Like some country managed their health system, and the other used lockdown and some have only adopted the preventive measures. Germany paid great attention to upgrade and manage the public health; however, Vietnam with some basic early preventive measures contained the spread much better while Taiwan used technologies and different strategy to handle the crisis. 
Basing on these examples, it might be seen that all the responses aimed to stop it from cascading into a disaster; hence all have seen positive results.

\section{Author Statements}

\section{$\underline{\text { Author information }}$}

Research Associate at Sanrachna, SGT University, Gurugram

\section{Competing interest}

None

\section{References}

1 Coronavirus Update (Live): 7,824,695 Cases And 430,582 Deaths From Covid-19 Virus Pandemic - Worldometer [Internet]. Worldometers.Info. 2020. Https://Www. Worldometers.Info/Coronavirus/

2 Strategic Preparedness And Response Plan. Who.Int. 2020. Https://Www. Who.Int/Docs/Default-Source/Coronaviruse/Srp04022020.Pdf? Ua=1

3 Shaw R, Kim Y, Hua J. Governance, Technology And Citizen Behavior In Pandemic: Lessons From Covid-19 In East Asia [Internet]. National Center For Biotechnology Information. 2020.

Https://Www.Ncbi.Nlm.Nih.Gov/Pmc/Articles/Pmc7194878/Pdf/Main.Pdf

4 Wang C, Ng C, Brook R. Response To Covid-19 In Taiwan [Internet]. Https://Jamanetwork.Com/. 2020.

Https://Jamanetwork.Com/Journals/Jama/Fullarticle/2762689

5 Coronavirus Update (Live): 7,824,695 Cases And 430,582 Deaths From Covid-19 Virus Pandemic - Worldometer.

Worldometers.Info. 2020. Https://Www.Worldometers.Info/Coronavirus/

6 G Baker M, Kvalsvig A, J Verrall A, J Aust M. New Zealand's Elimination Strategy For The Covid-19 Pandemic And What Is Required To Make It Work| Open Access [Internet]. Nzma.Org.Nz. 2020. Https://Www.Nzma.Org.Nz/Journal-Articles/New-

Zealands-Elimination-Strategy-For-The-Covid-19-Pandemic-And-What-Is-Required-To-Make-It-Work

7Cousins S. New Zealand Eliminates Covid-19. Thelancet.Com. 2020. Https://Www.Thelancet.Com/Action/Showpdf?Pii=SO1406736\%2820\%2931097-7

8 Covid-19(Novel Coronavirus). Ministry Of Health Nz. 2020. Https://Www.Health.Govt.Nz/Our-Work/Diseases-AndConditions/Covid-19-Novel-Coronavirus

9 Narlikar A. The Good, The Bad, And The Ugly: Germany's Response To The Covid-19 Pandemic| Orf Orf. 2020. Https://Www.Orfonline.Org/Research/The-Good-The-Bad-And-The-Ugly-Germanys-Response-To-The-Covid-19-Pandemic-66487/ 
10 Beyond Containment: Health Systems Responses To Covid-19 In The Oecd [Internet]. Oecd.Org. 2020 [Cited 28 May 2020]. Available From: Http://Www.Oecd.Org/Coronavirus/Policy-Responses/Beyond-Containment-Health-Systems-Responses-To-Covid19-In-The-Oecd-6ab740c0/

11 Coronavirus Update (Live): 7,824,695 Cases And 430,582 Deaths From Covid-19 Virus Pandemic - Worldometer . Worldometers.Info. 2020. Bhttps://Www.Worldometers.Info/Coronavirus/

12 Desborough J, L Hall S, De Toca L, Davis S, Roberts L. Australia's National Covid-19 Primary Care Response. Mja.Com.Au. 2020. Https://Www.Mja.Com.Au/System/Files/2020-04/Desborough\%20preprint\%2029\%20april\%202020.Pdf

13 Effects Of Covid-19 On Global Healthcare Systems | Ibisworld Industry Insider [Internet]. Ibisworld.Com. 2020.

Https://Www.Ibisworld.Com/Industry-Insider/Coronavirus-Insights/Effects-Of-Covid-19-On-Global-Healthcare-Systems/

14 H.D. Nguyen T. Summary Of The Covid-19 Outbreak In Vietnam - Lessons And Suggestions. National Center For Biotechnology Information. 2020.

Https://Www.Researchgate.Net/Publication/340608894_The_Largest_Epicenter_Of_The_Coronavirus_Outbreak_In_Vietnam

15 Southeast Asia Covid-19 Tracker. Csis.Org. 2020. Https://Www.Csis.Org/Programs/Southeast-Asia-Program/Southeast-AsiaCovid-19-Tracker-0 